\title{
The Asymmetrical Behavior of Cost: Evidence from Jordan
}

\author{
Jamal Abu-Serdaneh ${ }^{1}$ \\ ${ }^{1}$ Faculty of Business Studies, Arab Open University, Amman, Jordan \\ Correspondence: Jamal Abu-Serdaneh, Arab Open University, P. O. 1339, Code 11953, Amman, Jordan. Tel: \\ 962-6-563-0630. E-mail: J_serdaneh@aou.edu.jo
}

Received: May 25, 2014

doi:10.5539/ibr.v7n8p113
Accepted: June 24, 2014

Online Published: July 25, 2014

URL: http://dx.doi.org/10.5539/ibr.v7n8p113

\begin{abstract}
The study investigates whether different types of cost accounts are sticky or anti-sticky cost behavior using all listed Jordanian manufacturing companies during the period 2008-2012. Also, the study examines the effect of some explanatory factors on cost stickiness. These factors are asset intensity, debt intensity, free cash flow and growth.

The study finds anti-sticky cost behavior for cost of goods sold, and selling expenses, while the cost behavior for SG\&A and Administration costs is found to be symmetric, exhibiting neither stickiness nor anti-stickiness. The CGS model shows higher degree of stickiness for companies that have higher asset intensity, and less degree of stickiness for free cash flow. Also, less degree of stickiness is found for growth in the GDP declining period (pessimistic period) as in the case of Jordan. On the other hand, selling expenses model shows higher degree of stickiness for free cash flow and a less degree of stickiness is found for debt intensity.
\end{abstract}

Keywords: anti-sticky cost, cost asymmetry, cost behavior, sticky cost

\section{Introduction}

The traditional cost behavior postulates that activity costs change proportionately with activity volume change and treats costs as fixed or variable, which assume that variable costs automatically change symmetrically with change in the activity driver (Noreen, 1991; Noreen \& Soderstrom, 1997). However recent research (e. g. Anderson et al., 2003; 2009; Roodzant, 2012; Via \& Perego, 2013) documents an asymmetric response of costs to increase and decrease in activity, which addresses an important area of management and cost accounting.

Asymmetric cost is the phenomenon that the cost response to a decline in activity is smaller or greater than the cost response to an increase in activity; such cost behavior was identified as sticky or anti-sticky cost behavior. This behavior is justified in different ways, but the most repeated explanation was related to cost-benefit management capacity decisions in the face of changing demand; the cost of retains or decrease of unused capacity when management faced with falling demand (Cannon, 2011).

The purpose of this paper is investigating whether Jordanian manufacturing companies have sticky or anti-sticky cost behavior; whether cost change at the same rate when activity increases versus when they decrease. Also, the study examined specific factors hypothesized to influence cost behavior, and build different models to examine the factors influencing this behavior.

A clear understanding of cost behavior is very important in management accounting. Cost behavior is core for many decisions such as budgeting, controlling, and compensation decisions. This paper has two major contributions. First it is one of the very rare, if not the unique, papers which investigates the degree of sticky cost behavior in Jordanian firms. The second contribution is building several cost behavior models to capture the effect of company characteristics, and cost types.

The study proceeds as follows: Section 2 reviews the literature of sticky cost, section 3 develops the study hypotheses, section 4 provides the study methodology, section 5 tests and reports results, and section 6 concludes the study.

\section{Literature Review}

Reviewing of literature indicates academic interest in exploring whether cost behavior is sticky, and understanding the reasons, implications, and determinants of such behavior. This area of research is considered relatively new when prior studies such as Noreen and Soderstorm (1997) dispute that some costs increase more 
rapidly with an activity increase than they decrease with an activity decrease, and which is considered a curious pattern from traditional cost model and they fail to find evidence of this behavior. This argument was consistent with assertions in the activity-based costing literature when Cooper and Kaplan (1998) found that managers tend to increase costs more than to decrease costs.

Anderson, Banker, and Janakiraman (2003) (henceforth ABJ) and many subsequent studies (e. g. Balakrishnan et al., 2004; Anderson et al., 2006; Chen et al., 2012; Via \& Perego, 2013) provided evidence that costs behave asymmetrically in relation to firm activity. The earliest empirical study ABJ finds, for 7,629 US firms over 20 years, that selling, general and administrative (henceforth SG\&A) costs increase on average $0.55 \%$ per $1 \%$ increase in sales but decrease only $0.35 \%$ per $1 \%$ decrease in sales. They label this type of cost behavior as "sticky". Also, after a decade Roodzant (2012) finds, for 39,738 US-listed firms over the recent 14 years, that US firms still exhibit significant asymmetrical SG\&A cost behavior. Specifically, SG\&A costs increase with 0.46 percent following a one percent increase in activity and decrease with 0.32 percent following a one percent decrease in activity.

He et al., (2010) find that Japanese firms also demonstrate sticky SG\&A cost behavior similar to US firms. They find for 1802 firms over 25 years, that SG\&A costs increased on average $0.59 \%$ per $1 \%$ increase in sales but fell only $0.45 \%$ per $1 \%$ decrease in sales. Calleja et al. (2006) observe cost stickiness on operating costs using samples of the U.S., U.K., French, and German firms. Specifically, they find that the stickiness on operating costs of French and German firms are stronger than the costs on the U.S. and U.K. firms.

Banker and Chen (2006) examining cross-country differences in the sticky behavior of operating expense; Using a sample 12,666 firms from 19 countries that are members of the Organization for Economic Co-operation and Development (OECD) during the period 1996-2005, they document that the degree of stickiness in operating expense varies significantly across firms in different countries. The study provides strong empirical support that labor market characteristics are important determinants of across-country variations in the degree of cost stickiness.

Rhee et al. (2012) examined the total costs including SG\&A of Korean manufacturing industry. They used different models to find if cost stickiness is affected by controlling price effect by customer price index method, and without controlling price effect. Rhee et al. (2012) figure out that no notable difference in the magnitude of cost stickiness in each two conditions (controlled and uncontrolled price effect). Incorporation inflation in the sticky cost model by eliminating price effect take place in some prior literature (e.g., Balakrishnan \& Gruca, 2008; ROODZANT, 2012). Meanwhile many other studies examined sticky cost without incorporation inflation effect (e.g., Chen et al., 2008; Sorros \& Karagiorgos, 2013).

Sticky cost literature depicted that cost stickiness varies across different industries. Özkaya and Yükcü (2011) investigate whether SG\&A Costs and Total Operating Costs are sticky for nonfinancial Turkish firms over 20 years. They find that the degree of stickiness of SG\&A Costs is slightly higher for manufacturing firms than nonmanufacturing firms and the opposite is true for Total Operating Costs. On the other hand in banking sector, Porporato Werbin (2012) confirms the existence of sticky costs in the banks of Argentina, Brazil and Canada for 2004-2009. The study argued that total costs in this industry follow a sticky behavior because the magnitude of the increase associated with an increase in the volume of activity or revenues $(0.60 \%, 0.82 \%$ and $0.94 \%)$ is larger than the magnitude of the fall associated with a decrease of the volume $(0.38 \%, 0.48 \%$ and $0.55 \%)$. Also, sticky cost behavior proved in other sectors such as hospitals (e.g., Balakrishnan et al., 2007; Balakrishnan \& Gruca, 2008), transportation industry (e.g., Cannon, 2011), and in other service sectors (e.g., Anderson, et al., 2004).

The justification of this behavior by $\mathrm{ABJ}$ as there is uncertainty about future demand and firms must incur adjustment costs to reduce or restore committed resources; managers may purposely delay reductions to committed resources until they are more certain about the permanence of a decline in demand (p. 3). Another justification for sticky cost behavior is based on managerial empire building; the manager tendencies to grow the firm beyond its optimal size or to maintain unutilized recourses with the purpose of increasing utility from status, power, and prestige (Masulis et al., 2007; Hope \& Thomas, 2008; Chen et al., 2012).

However, it is not expected that all costs to be sticky in all circumstances. On the contrary, based on the economic foundations of cost stickiness, the degree of cost stickiness could vary systematically across different cost accounts, firms, industries and countries, including the possibility of no stickiness or anti-stickiness (Anderson et al., 2009). Anti-stickiness means that costs increase less for increases in sales than they decrease for decreases in sales (Weiss 2010).

(Anderson et al., 2009) find evidence of sticky SG\&A costs in a larger, 27-year sample, the results are not robust 
for many important sub-samples. The sticky cost behavior for other types of costs that are also subject to managerial discretion (including: advertising, labor wages, headcount, research and development, and property, plant and equipment). They find no consistent mode of cost behavior; cost changes are almost equally likely to exhibit asymmetries of both the sticky and "anti-sticky". However, (Banker et al. 2011) argue that despite anti-sticky empirical evidence (e. g., Goux et al. 2001, Cooper and Haltiwanger 2006, Anderson et al., 2009) reinforces the expectation for costs to be sticky on average.

Adjusting committed resources is costly, due to adjustment costs such as hiring and firing costs for labor, or installation and disposal costs for machinery (Cooper \& Haltiwanger 2006). This gives rise to a more complex dynamic relation between changes in costs and changes in sales, leading to patterns of cost stickiness and anti-stickiness.

Another important driver of sticky and anti-sticky cost behavior is managers' incentives when their compensation is linked to profit or stock prices that are related to reported profit (Banker et al. 2011). Agency issues may diminish or reinforce cost stickiness, depending on the circumstances (e.g., Chen et al. 2008, Kama \& Weiss, 2013).

Many factors are hypothesized to influence cost stickiness, a more body of literature document the relationship between the degree of sticky cost behavior and corporate government (e.g., Calleja et al., 2006; Chen et al., 2008; 2012), another explanatory factors of stickiness associated with firm-specific characteristics such as asset intensity, employees intensity and debt intensity (e.g., Anderson et al., 2003, Banker, 2006; Chen et al., 2012; Via \& Perego, 2013). Also, another literature examined the impact of country- specific characteristics such as growth, labor market, and regulations on the degree of sticky cost behavior (e.g., Banker \& Chen, 2006; Dierynck \& Renders, 2009; He et al., 2010; Banker et al., 2011; Chen et al., 2012), while other literature focused on the managerial incentives and empire building factors (e.g., Banker et al., 2011; Chen et al., 2012) to justify the effect of agency theory on the sticky cost behavior.

\section{Hypothesis Development}

Sticky cost behavior described as an asymmetric cost response to increases and decreases in activity. The predominant explanation for sticky costs is that management leaves capacity unchanged as demand falls (Cannon, 2011). Based on this argument, the first hypothesis is:

H1: Cost behavior is sticky on average; costs typically increase more for a one percent increase in activity than they decrease for an equivalent decrease in activity.

Different cost accounts could lead to different results or at least to different degrees of stickiness. Several studies build on ABJ model and focusing on SG\&A (e.g., Anderson et al. 2004; Banker et al., 2006; Anderson et al., 2009; Balakrishnan et al., 2010; Chen et al., 2012). Repeating SG\&A costs in literature because such type of cost widely available for all types of firms, and its behavior can be meaningfully studied in relation to revenue activity because sales volume drivers many of the component of SG\&A (Cooper \& Kaplan, 1998). Another reason for selecting SG\&A costs is its importance, since on average, the SG\&A costs to total assets ratio is 27 percent, compared to the research and development to total asset ratio of 3 percent (Banker, et al., 2011).

However, other cost accounts applied in literature; for example (Anderson et al., 2009) examine advertising, salaries, headcount, research and development, and property, plant and equipment cost accounts; and found different degrees of stickiness. Subramaniam and Weidenmier (2003) examine the behavior of SG\&A and cost of goods sold and find that both of two accounts reveal sticky behavior in average but the results are different by different industries. Via and Perego (2013) examined the cost of goods sold on the small and medium sized Italian companies, and a non-sticky behavior exhibited by this type of costs compared with labor costs.

Based on this argument, the second hypothesis is:

H2: The degree of cost stickiness differs with different cost accounts.

Several empirical studies have focused on firm factors that explain cost stickiness and explain why managers used to wait longer to adjust resources downward. For example, ABJ, Subramaniam and Weidenmier (2003), Calleja et al., (2006), and Via and Perego, (2013) examined different specific firm- based measures of intensity: assets intensity, employees intensity, debt financing intensity, and working capital intensity. Other research examined corporate governance characteristics (e.g., Calleja et al., 2003; 2006; Chen et al., 2008; 2012), cost structure (Homburg \& Nasev, 2008; Balakrishnan et al., 2010), technological constraints (Anderson \& Lanen, 2007; Kama \& Weis, 2010), conditional conservatism or good news or bad news factor (Ball \& Shivakumar, 2005; Beaver \& Ryan, 2005), industry (Subramaniam \& Weidenmier, 2003; Anderson \& Lanen, 2009; Via \& Perego, (2013), agency theory and empire-building factors (Richardson, 2006; Chen et al., 2008; 2012), and 
growth (e.g., Banker \& Chen, 2006; Dierynck \& Renders, 2009; He et al., 2010; Banker et al., 2011; Chen et al., 2012).

In this study, four specific factors will be examined based on its importance in the literature and information availability, these factors are: asset intensity, debt intensity, managerial empire building, and growth. Industry factor not incorporated because the study sample applied on all manufacturing companies, which have similar cost structure.

Many studies tested the impact of asset intensity on cost stickiness. Sorros and Karagiorgos, (2013) argued that it is relatively easy to scale down purchased resources when demand drops, but disposing of assets is costly because the company must pay selling costs and lose firm-specific investments. ABJ and Via and Perego (2013) empirical results suggested that bigger firms in terms of assets intensity have a more sticky behavior. The justification of such relationship is linked with the costs faced retaining surplus resources compared to the costs for renegotiating the levels of resources.

based on this argument, the third hypothesis is:

H3: Firm's asset intensity is positively associated with the degree of cost stickiness.

Beside to asset intensity, some empirical studies tested debt intensity (e. g., Subramaniam \& Weidenmier, 2003; Calleja et al., 2006; Via \& Perego, 2013), debt intensity appeared positive relationship with cost behavior. Calleja et al. (2006) conclude that firms with higher levels of debt exhibit no cost stickiness since managers are pushed by creditors to meet payments. Via and Perego, (2013) supported this argument, and revealed that manufacturing companies with a high level of debt tend to reduce SG\&A costs.

based on this, the fourth hypothesis is:

\section{H4: Firm's debt intensity is negatively associated with cost stickiness.}

The cross- country differences in GDP growth patterns, and the differences of GDP from year to year in the same country lead to substantial differences in the cost behavior (Sorros \& Karagiorgos, 2013). A significant relationship between GDP and cost behavior found in ABJ, Banker and Chen (2006), and He et al., (2010). But a contrary results found by Calleja et al., (2006). Managers are more likely to hold excess capacity in macroeconomic growth periods as a result of optimistic expectations (Banker et al., 2011 applied GDP growth as proxies for managers optimism and pessimism). Therefore, costs behavior will be more sticky with the higher the economic growth.

Based on this argument, the fifth hypothesis is:

\section{H5: GDP growth is positively associated with the degree of cost stickiness.}

Empire building, which refers to managers' tendencies to grow the firm beyond its optimal size or to maintain unutilized resources with the purpose of increasing personal utility from status, power, compensation, and prestige (Chen et al., 2012). Such behavior will result in greater cost stickiness. This implies a positive relation between the agency problem and the degree of cost stickiness. Chen et al. (2008) and Banker et al., (2011) find a positive association between empire-building behavior and the degree of cost stickiness. They argue that managers empire-building behavior more reluctant to reduce resources at their disposal when sales decline, and more willing to increase resources at their disposal when sales increase

Free cash flow (FCF) is a commonly used proxy for the agency problem and the resulting empire building incentives (Richardson 2006; Masulis et al., 2007; Chen et al., 2008; 2012; Banker et al., 2011). Jensen (1986) proposed that managers with high levels of FCF are likely to invest it in operations or negative net present value projects instead of paying it out to shareholders in order to increase perquisites consumption. Chen et al., (2012, p. 256) proposed that when FCF is high, managers have greater opportunity for overinvesting in operational costs in response to an increase in output demand and delaying the cutting costs in response to a decrease in output demand, leading to greater cost stickiness. By contrast, when FCF is low, managers have less opportunity for empire building and they are more likely to reduce costs in response to demand decreases in order to avoid negative career consequences.

Based on this argument, the sixth hypothesis is:

H6: Firm's free cash flow is positively associated with the degree of cost stickiness.

\section{Study Methodology}

\subsection{Study Sample and Data}

The study has obtained data on different cost accounts (SG\&A, cost of goods sold, selling expenses, 
Administration expenses), sales revenues, and other required data from the annual reports of all manufacturing companies listed at Amman Stock Exchange for five years (2008-2012).

The following criteria applied to screen data, such criteria followed by many prior literature (e. g., ABJ, 2003; Anderson et al. 2009): (1) Delete observations that are missing data. (2)Eliminate those extreme observations where the value of any variables is in the upper or lower $0.5 \%$. The total number of companies that comply with the criteria is 62 .

In this study all firms belonging to the non-manufacturing industry; trading and service firms are not considered because of their different cost structure and business approach.

\subsection{Study Models}

Many of empirical studies measured cost stickiness using the sticky cost regression model of ABJ (e. g., Balakrishnan et al., 2004; Anderson et al., 2006; Chen et al., 2012; Via \& Perego, 2013). The same model will be applied in this study in different forms to test the study hypotheses.

To test the first hypothesis, different cost types are applied (SG\&A, cost of goods sold, selling expenses, Administration expenses), but SG\&A was repeated in the literature because such type of cost is widely available for all types of firms and its important and significant effect compared with other cost accounts.

\section{Model 1:}

$\log \left[S G \& A_{i t} / S G \& A_{i, t-1}\right]=\beta 0+\beta 1 * \log \left[\right.$ Sales $_{i, t} /$ Sales $\left._{i, t-1}\right]+\beta 2 * D D_{t} * \log _{\left[\text {Sales }_{i, t}\right.} /$ Sales $\left._{i, t-1}\right]+\varepsilon_{i, t}$

Where $\mathrm{SG} \& \mathrm{~A}_{\mathrm{i}, \mathrm{t}}$ and $\mathrm{Sales}_{\mathrm{i}, \mathrm{t}}$ are selling, general, and administrative costs and sales revenue respectively, for firm $i$ at year t. Decrease Dummy $\left(D_{t}\right)$ takes the value of one when sales revenues in year $t$ are less than those in year t-1 and zero otherwise. Coefficient B1 measures the percentage increase in SG\&A costs with a 1 percent increase in sales revenue. Because the value of DD is one when revenue decreases, the sum of the coefficients $(\mathrm{B} 1+\mathrm{B} 2)$ measures the percentage decrease in SG\&A costs with a 1 percent decrease in sales revenue. A significantly positive coefficient B1 and a significantly negative coefficient B2 would be consistent with cost stickiness.

To test the second hypothesis, the previous model will be applied but with different cost accounts. The model will be repeated to examine other cost accounts. These cost accounts available for all study sample as a requirement of Jordan Securities Commission.

To test the remaining hypothesis (H3-H6) related to the four factors affecting sticky cost, model one is expanded as the following:

Model 2:

$\log \left[S G \& A_{i t} / S G \& A_{i, t-1}\right]=\beta 0+\beta 1 * \log \left[\right.$ Sales $_{i, t} /$ Sales $\left._{i, t-1}\right]+\beta 2 * D D_{t} * \log _{\left[\text {Sales }_{i, t}\right.} /$ Sales $\left._{i, t-1}\right]+\beta 3 * D D_{t}$

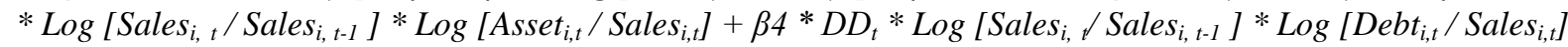

$+\beta 5 * D D_{t} * \log \left[\right.$ Sales $_{i, t} /$ Sales $\left._{i, t-1}\right] * \log _{\left[F C F_{i, t}\right.} /$ Sales $\left._{i, t}\right]+\beta 6 * D_{t} *$ Log $_{\text {[Sales }}, t /$ Sales $\left._{i, t-1}\right] *$ GDP

where $\log \left[\right.$ Asset $_{\mathrm{i}, \mathrm{t}} /$ Sales $\left._{\mathrm{i}, \mathrm{t}}\right]$ is used to measure asset intensity, $\log \left[\right.$ Debt $\left._{\mathrm{i}, \mathrm{t}} / \mathrm{Sales}_{\mathrm{i}, \mathrm{t}}\right]$ is used to measure total debt intensity, $\log \left[\mathrm{FCF}_{\mathrm{i}, \mathrm{t}} / \mathrm{Sales}_{\mathrm{i}, \mathrm{t}}\right]$ is used to measured free cash flow as a proxy for empire building incentives, and GDP is used as a proxy to measure growth rate.

All variables in the model (except growth) are log-transformed to obtain a better normal distribution and enhance economic interpretation.

\section{Tests and Results}

\subsection{Descriptive Statistics}

Table 1 provides descriptive analysis on all study variables to explore basic data and characteristics of Jordanian manufacturing companies. Bad performance is characterizing the targeted companies during the period of study; the GDP growth variable showed dramatic decline from $8 \%$ on 2007 to $2.3 \%$ on 2010 and improved to $2.8 \%$ on 2012. Also, the collected data showed that about one third of observations with negative operating cash flow with $3 \%$ average free cash flow of sales, while average of asset to sales and debt to sales was around $250 \%$ and $100 \%$ respectively, which reflect high debt percentage and low asset utilization. This conclusion can be supported from profitability indicators which showed that about one third of companies achieved losses and the profitability ratio average is around $-3 \%$. The decrease dummy variable is repeated as value one (the value of one when sales revenues in year $t$ are less than those in year $t-1$ ) in about half of observations. 
Table 1. Descriptive analysis

\begin{tabular}{lcccc}
\hline & Minimum & Maximum & Mean & Std. Deviation \\
\hline FCF/Sales & $(1.34)$ & 0.83 & 0.03 & 0.27 \\
asset/Sales & 0.14 & 19.49 & 2.54 & 2.80 \\
debt/Sales & 0.04 & 16.89 & 1.02 & 2.00 \\
total assets & 277285 & 1008039000 & 46829595 & 125565268 \\
total liability & 23699 & 231388000 & 15720318 & 33984734 \\
total sales & 56112 & 846891895 & 33065902 & 99469861 \\
cost of goods sold & 65939 & 483739864 & 21314683 & 55869124 \\
general and adm. expenses & 61496 & 31050203 & 1377918 & 3807630 \\
selling expenses & 2857 & 15504000 & 1320277 & 2770652 \\
Operating expenses & 70771 & 36540000 & 2698195 & 5873469 \\
GDP (Growth) & $2.31 \%$ & $8.18 \%$ & $4.77 \%$ & $2.56 \%$ \\
cash flow & $(3931429)$ & 252489000 & 6263928 & 30227934 \\
Free Cash Flow & $(5421663)$ & 194166750 & 4160526 & 21581730 \\
\hline
\end{tabular}

\subsection{Hypotheses Testing}

Specific assumptions must be met when undertaking regression statistical analysis. For all models that the study estimate, multicollinearity diagnostic tests are conducted. The Variances Inflation Factor (VIF) is lower than 10 and the tolerance statistic is higher than 0.1 for all variables, which indicate that the independent variables are not highly correlated according to Myers (1990) and Field (2001).

Also, standardized residuals examined to test linearity and Durbin-Watson is examined to test independent error, the results showed that $95 \%$ of the cases have standardized residuals within -2 and +2 , and the correlation between errors varies between 0 and 4 .

The results of two models for all cost types (SG\&A, Cost of Goods Sold, Selling, Administration) are presented in Table 2. A direct comparison between different cost types showing different results, proves the second hypothesis "The degree of cost stickiness differs with different cost accounts". All values obtained for B1 in model 1 and model 2 reveals a significant positive coefficient, the SG\&A costs increase by $0.357 \%$ for $1 \%$ increase in sales, the cost of goods sold (CGS) increased by $0.741 \%$ for $1 \%$ increase in sales, the selling costs increased by $0.517 \%$ for $1 \%$ increase in sales, the administration costs increased by $0.236 \%$ for $1 \%$ increase in sales.

Because the value of decrease dummy (DD) is one when sales decrease; the sum of coefficient (B1+B2) measure the percentage decrease in cost type with $1 \%$ decrease in sale. A significantly positive coefficient B1 and a significantly negative coefficient $\mathrm{B} 2$ would be consistent with sticky cost behavior, while a significantly positive coefficient for both B1 and B2 would be consistent with anti-sticky cost behavior "for a $1 \%$ revenue decrease other type of cost decline more than they increase for a growth in revenue of 1\%" (Via \& Perego, 2013, p. 18). The model 1 results present that B2 for SG\&A and Administration costs are not significant at $10 \%$, and positively significant for CGS and selling expenses at $1 \%$ and 5\% respectively. Accordingly, a non-sticky or anti-sticky behavior exhibited by CGS and selling expenses, the CGS decreased by $0.923 \%$ for $1 \%$ decrease in sales, the selling costs decreased by $0.84 \%$ for $1 \%$ decrease in sales.

The anti-sticky behavior of CGS and selling expenses does not agree with the first hypothesis "Cost behavior is sticky on average ", since CGS and selling expenses increase $0.741 \%$ and $0.517 \%$ respectively for $1 \%$ increase in sale and decrease $0.923 \%$ and $0.84 \%$ for $1 \%$ decrease in sale. This result align with (Balakrishnan et al., 2004; 2010; Weiss 2010; Via \& Perego, 2013) results. They found that some types of costs (especially CGS) are anti-sticky on average.

Banker et al. (2010) defend anti-stickiness behavior and connect with economic expectations, they argue that cost stickiness is estimated to be found when the expectations for the future are optimistic, but anti-stickiness when the expectations for the future are pessimistic. This argument can be applied on Jordan case, since the country is facing dramatic decline in the GDP, and the industrial companies appeared to have bad profitability 
and operating cash flow performance.

Table 2 also presents also the coefficients of the other explanatory variables. The models 1 and 2 results present that the coefficients of most explanatory variables for SG\&A and Administration costs are not significant at 10\%, and for this reason, the study considerations will be limited to other types of costs. No significant results in most of explanatory variables especially in B2 are repeated in some prior literatures such as (Via \& Perego, 2013) and in four countries of Banker et al. (2011) study (UK, Brazil, Sweden, and South Africa).

The CGS results show a significant and negative association for asset intensity $(-0.168$ at $10 \%)$. However a significant and positive sign is associated to the Growth (4.371 at $1 \%)$ and free cash flow (0.094 at 10\%). On the other hand, different results appeared with selling costs; a significant and negative association for free cash flow $(-2.31$ at $5 \%)$ and a significant and positive sign is associated to the debt intensity $(0.93$ at $5 \%)$

The asset intensity results agree with several studies that examined this factor and found that the degree of stickiness in costs is in fact higher for companies that have higher asset intensity, which means that high levels of assets intensity increase the stickiness of CGS (e.g., ABJ, 2003; Subramaniam \& Weidenmier, 2003; Banker et. al., 2011, Via \& Perego, 2013). Therefore, the third hypothesis which postulates the positive association between asset intensity and the degree of cost stickiness is correct for CGS type.

Also, the fourth hypothesis assumed that a positive relationship between debt intensity and cost behavior is correct for selling expenses. Table 2 presents a positive and significant association $(0.793$ at $5 \%)$ for debt intensity. This result is similar to Calleja et al. (2006) and Via and Perego, (2013) results, and proved empirically that the high level of debt tend to reduce costs.

The results of growth variable (the fifth hypothesis) shows that there is a significant and positive association (4.371 at 1\%) with CGS behavior. This result agrees with prior literature results; as Banker et al. (2011) who have argued that cost behavior will be more sticky in macroeconomic growth periods because managers will have more optimistic expectations, and so more likely to hold excess capacity. In this study case, the Jordan macroeconomic faces dramatic decline (the GDP decreases from $8 \%$ to $2.5 \%$ ) and the manufacturing company achieved bad performance as mentioned earlier. Therefore, the growth variable effect should present less sticky behavior.

The results of FCF variable (the sixth hypothesis) which used as a proxy for the empire building appeared negative and significant association for selling expenses (-0.396 at 5\%), while the CGS shows positive and significant association $(0.094$ at $10 \%)$. This difference in the sign of significant association is justified in the literature (Masulis et al., 2007; Chen et al., 2008; 2012; Banker et al., 2011). First, managers empire-building behavior are more reluctant to reduce resources at their disposal when sales decline, and more willing to increase resources at their disposal when sales increase (FCF is positively associated with the degree of cost stickiness). Second, managers are more likely to reduce costs in response to demand decreases in order to avoid negative career consequences (FCF is positively associated with the degree of cost anti-stickiness). The poor operating cash flow during the study period justifies the second view point for CGS, whereas the sticky cost behavior in selling expenses reflects the managers' ambition to improve performance through selling and advertising activities.

Table 2. Results of regression models

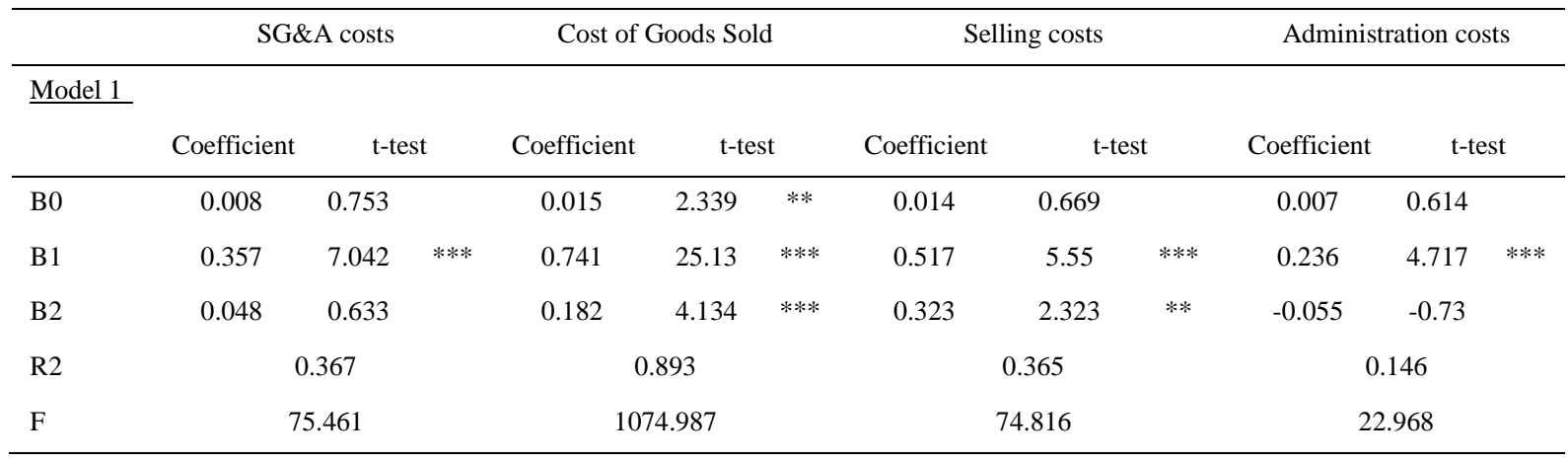




\begin{tabular}{|c|c|c|c|c|c|c|c|c|c|c|c|c|}
\hline \multirow{3}{*}{$\begin{array}{l}\underline{\text { Model } 2} \\
\text { B0 }\end{array}$} & \multirow{3}{*}{$\begin{array}{c}\text { Coefficient } \\
0.011\end{array}$} & \multirow{2}{*}{\multicolumn{2}{|c|}{ t-test }} & \multirow{3}{*}{$\begin{array}{c}\text { Coefficient } \\
0.017\end{array}$} & \multirow{2}{*}{\multicolumn{2}{|c|}{ t-test }} & \multirow{3}{*}{$\begin{array}{c}\text { Coefficient } \\
-0.003\end{array}$} & \multirow{2}{*}{\multicolumn{2}{|c|}{ t-test }} & \multirow{3}{*}{$\frac{\text { Coefficient }}{0.018}$} & \multirow{2}{*}{\multicolumn{2}{|c|}{ t-test }} \\
\hline & & & & & & & & & & & & \\
\hline & & 0.889 & & & 2.387 & $* *$ & & -0.14 & & & 1.526 & \\
\hline $\mathrm{B} 1$ & 0.352 & 6.789 & $* * *$ & 0.738 & 25.12 & $* * *$ & 0.549 & 5.881 & $* * *$ & 0.214 & 4.223 & $* * *$ \\
\hline B2 & 0.078 & 0.529 & & 0.143 & 1.725 & $*$ & 0.001 & 0.004 & & 0.202 & 1.411 & \\
\hline $\begin{array}{l}\text { B3 Asset } \\
\text { intensity }\end{array}$ & -0.215 & -1.23 & & -0.168 & -1.7 & $*$ & -0.302 & -0.96 & & -0.227 & -1.33 & \\
\hline $\begin{array}{l}\text { B4 Debt } \\
\text { intensity }\end{array}$ & 0.219 & 1.1 & & 0.058 & 0.515 & & 0.793 & 2.204 & $* *$ & 0.055 & 0.281 & \\
\hline $\begin{array}{l}\text { B5 Free } \\
\text { Cash Flow }\end{array}$ & -0.049 & -0.52 & & 0.094 & 1.748 & $*$ & -0.396 & -2.31 & $* *$ & 0.08 & 0.855 & \\
\hline B6 Growth & 1.678 & 0.748 & & 4.371 & 3.437 & $* * *$ & -0.556 & -0.14 & & 1.347 & 0.614 & \\
\hline $\mathrm{R} 2$ & & 0.379 & & & 398 & & & 0.386 & & & 162 & \\
\hline $\mathrm{F}$ & & 25.496 & & & 609 & & & 27.979 & & & 253 & \\
\hline
\end{tabular}

$*, * *, * * *$ indicate significance at $10 \%, 5 \%$, and $1 \%$ respectively.

\section{Conclusion}

This study investigates whether Jordanian Manufacturing Companies demonstrate sticky or anti-sticky cost behavior. Also, the study examines the effect of some explanatory factors on cost stickiness in Jordan. These factors are asset intensity, debt intensity, free cash flow and growth.

The study finds anti-sticky cost behavior for CGS and selling expenses, while the cost behavior for SG\&A and Administration costs are found to be symmetric, exhibiting neither stickiness nor anti-stickiness. This aligns with the argument that the degree of cost stickiness varies systematically across different cost accounts, firms, industries and countries, including the possibility of no stickiness or anti-stickiness.

The CGS model shows higher degree of stickiness for companies that have higher asset intensity, and less degree of stickiness for FCF, since managers are more likely to reduce costs in response to demand decreases in order to avoid negative career consequences. Also, less degree of stickiness is found for growth in the GDP declining period (pessimistic period) as in the case of Jordan.

On the other hand, selling expenses model shows higher degree of stickiness for FCF which reflects the managers' ambition to improve performance through selling and advertising activities, and a less degree of stickiness is found for debt intensity to reduce interest cost in the case of high level of debt.

This study is subject to some limitations. First, the study is applied on manufacturing companies; it is difficult to generalize the results of this sector to others because of their different cost structure and business approach. Second, the five years study data is related to recession period in Jordan economy; the cost behavior could be different in other periods. Third, the study only examined a limited number of variables (the most variables repeated in the literature), it is unclear how other explanatory factors might influence cost asymmetry.

\section{Acknowledgements}

This study is funded by a research grant from Arab Open University, Amman, Jordan.

\section{References}

Anderson, M., Banker, R., \& Janakiraman, S. (2003). Are selling, general, and administrative costs "sticky"? Journal of Accounting Research, 41(1), 47-63. http://dx.doi.org/10.1111/1475-679X.00095

Anderson, M., Banker, R., Chen, L., \& Janakiraman, S. (2004). Sticky Costs at Service Firms. Working Paper, University of Texas, Dallas.

Anderson, S. W., \& Lanen, W. N. (2009). Understanding cost management: What can we learn from the empirical evidence on sticky costs? Working paper, Rice University and University of Michigan. http://dx.doi.org/10.2139/ssrn.975135

Anderson, S. W., \& Widener, S. K. (2006). Doing Quantitative Field Studies in Management Accounting. Handbook of Management Accounting Research, 1. Oxford: Elsevier. http://dx.doi.org/10.2139/ssrn.833124 
Balakrishnan, R., \& Gruca, T. (2008). Cost stickiness and core competency: A note. Contemporary Accounting Research, 25(4), 993-1006. http://dx.doi.org/ 10.1506/car.25.4.2

Balakrishnan, R., Labro, E., \& Soderstrom, N. (2010). Cost structure and sticky costs. Working paper, The University of Iowa, University of North Carolina, and University of Colorado. http://dx.doi.org/10.2139/ssrn.1562726

Balakrishnan, R., Peterson, M., \& Soderstrom, N. (2004). Does capacity utilization affect the "stickiness" of cost? Journal of Accounting, Auditing and Finance, 19(3), 283-299. http://dx.doi.org/10.1177/0148558X0401900303

Balakrishnan, R., Soderstrom, N., \& West, T. (2007). Spending Patterns with Lapsing Budgets: Evidence from US Army Hospitals. Journal of Management Accounting Research, 19, 1-24. http://dx.doi.org/10.2308/jmar.2007.19.1.1

Ball, R., \& Shivakumar, L. (2005). Earnings quality in UK private firms: comparative loss recognition timeliness, Journal of Accounting and Economics, 39(1), 83-128. http://dx.doi.org/ 10.1016/j.jacceco.2004.04.001

Banker, R. D., \& Chen, L. (2006). Labor market characteristics and cross-country difference s in cost stickiness. Working paper, Georgia State University. http://dx.doi.org/10.2139/ssrn.921419

Banker, R. D., Ciftci, M., \& Mashruwala, R. (2010). Managerial optimism, prior period sales changes, and sticky cost behavior. Working paper. Temple University and University of Illinois. http://dx.doi.org/10.2139/ssrn.1599284

Banker, R., Byzalov, D., \& Plehn-Dujowich, J. M. (2011). Sticky cost behavior: Theory and evidence. Working paper, Temple University. http://dx.doi.org/10.2139/ssrn.1659493

Beaver, W., \& Ryan, S. (2005). Conditional and unconditional conservatism: concepts and modeling. Review of Accounting Studies, 10(2/3), 269-309. http://dx.doi.org/10.1007/s11142-005-1532-6

Calleja, K., Steliaros, M., \& Thomas, D. (2006). A note on cost stickiness: Some international comparisons. Management Accounting Research, 17, 127-140. http://dx.doi.org/ 10.1016/j.mar.2006.02.001

Cannon, J. N. (2011). Determinants of 'Sticky Costs': An Analysis of Cost Behavior using United States Air Transportation Industry Data. AAA 2012 Management Accounting Section (MAS) Meeting Paper. http://dx.doi.org/10.2139/ssrn.1895615

Chen, C. H., Lu, H., \& Sougiannis, T. (2008). Managerial empire building, corporate governance, and the asymmetrical behavior of selling, general, and administrative costs. AAA 2008 Financial Accounting and Reporting Section (FARS) Paper; (CAAA) 2008 Annual Conference Paper. http://dx.doi.org/10.2139/ssrn.1014088

Chen, C. X., Lu, H., \& Sougiannis, T. (2012). The agency problem, corporate governance, and the asymmetrical behavior of selling, general, and administrative costs, Contemporary Accounting Research, 29(1), 252-282. http://dx.doi.org/10.1111/j.1911-3846.2011.01094.x

Cooper, R., \& Haltiwanger, J. (2006). On the nature of capital adjustment costs. Review of Economic Studies, 73, 611-633. http://dx.doi.org/10.3386/w7925

Cooper, R., \& Kaplan, R. (1998). The design of cost management systems: text, cases, and readings. Upper Saddle River, NJ: Prentice-Hall.

Dierynck, B., \& Renders, A. (2009). Earnings management incentives and the asymmetric behavior of labor costs. Working paper, Tilburg University. http://dx.doi.org/10.2139/ssrn.1441250

Field, A. (2001). Discovering statistics using SPSS for Windows, advanced techniques for the beginner. London, Sage.

Goux D., Maurin, E., \& Pauchet, M. (2001). Fixed-term contracts and the dynamics of labour demand. European Economic Review, 45, 533-552. http://dx.doi.org/10.1016/S0014-2921(00)00061-1

He, D., Teruya, J., \& Shimizu, T. (2010). Sticky Selling, General, and Administrative Cost Behavior and its Changes in Japan. Global Journal of Business Research, 4(4), 1-10. Retrieved from http://ssrn.com/abstract=1871276

Homburg, C., \& Nasev, J. (2008). How timely are Earnings when Costs are Sticky? Implications for the Link between Conditional Conservatism and Cost Stickiness. AAA 2009 Management Accounting Section (MAS) Meeting Paper. http://dx.doi.org/10.2139/ssrn.1187082 
Hope, O., \& Thomas, W. B. (2008). Managerial empire building and firm disclosures. Journal of Accounting Research, 46(3), 591-626. http://dx.doi.org/10.2139/ssrn.997864

Jensen, M. C. (1986). Agency costs of free cash flow, corporate finance, and takeovers. American Economic Review, 76(3), 323-29. http://dx.doi.org/10.2139/ssrn.99580

Kama, I., \& Weiss, D. (2013). Do Earnings Targets and Managerial Incentives Affect Sticky Costs. Journal of Accounting Research, 5(1), 201-224. http://dx.doi.org/10.1111/j.1475-679X.2012.00471.x

Masulis, R. W., Wang, C., \& Xie, F. (2007). Corporate governance and acquirer returns. The Journal of Finance, 62(4), 1851-89. http://dx.doi.org/10.2139/ssrn.697501

Myers, R. H. (1990). Classical and modern regression application (2nd ed). California, CA: Duxbury press.

Noreen, E. (1991). Conditions under which Activity-based Cost Systems Provide Relevant Costs. Journal of Management Accounting Research, 3(Fall), 159-168.

Noreen, E., \& Soderstrom, N. (1997). The accuracy of proportional cost models: Evidence from hospital service departments. Review of Accounting Studies, 2, 89-114. http://dx.doi.org/10.1023/A:1018325711417

Özkaya, H., \& Yükcü, S. (2011). Cost Behavior in Turkish Firms: Are Selling, General and Administrative Costs and Total Operating Costs "Sticky"? World of Accounting Science, 13(3), 1-27.

Porporato, M., \& Werbin, E. (2010). Active cost management in banks: Evidence of sticky costs in Argentina. Brazil and Canada, AAA 2011 Management Accounting Section (MAS) Meeting Paper. http://dx.doi.org/10.2139/ssrn.1659228

Rhee, C. S., Kim, J., \& Lee, S. (2012). Sticky Cost Behavior: Quantity Based Approach. AAA 2012 Management Accounting Section (MAS) Meeting Paper. Retrieved from http://aaahq.org/AM2012/abstract.cfm?submissionID=846

Richardson, S. (2006). Over-investment of free cash flow. Review of Accounting Studies, 11(2-3), 159-89. http://dx.doi.org/10.1007/s11142-006-9012-1

Roodzant, C. H. (2012). Cost Behavior and Prior Year Earnings: Evidence for US-listed Firms (Unpublished master's thesis). Tilburg University, Netherlands.

Sorros, J., \& Karagiorgos, A. (2013). Understanding Sticky Costs and the Factors Affecting Cost Behavior: 'Cost Stickiness Theory and its Possible Implementations'. http://dx.doi.org/10.2139/ssrn.2239368

Subramaniam, C., \& Weidenmier, M. L. (2003). Additional evidence on the sticky behavior of costs. Working paper. http://dx.doi.org/10.2139/ssrn.369941

Via, N. D., \& Perego, P. (2013). Sticky cost behavior: Evidence from small and medium sized companies. Accounting \& Finance, Forthcoming. http://dx.doi.org/10.2139/ssrn.2226399

Weiss, D. (2010). Cost behavior and analysts' earnings forecasts. The Accounting Review, 85(4), 1441-1471. http://dx.doi.org/10.2308/accr.2010.85.4.1441

\section{Copyrights}

Copyright for this article is retained by the author(s), with first publication rights granted to the journal.

This is an open-access article distributed under the terms and conditions of the Creative Commons Attribution license (http://creativecommons.org/licenses/by/3.0/). 